The minor changes in composition after 14 days of storage suggest that 'Manoa Sugar' peas can be stored for 2 weeks at temperatures that are higher than the recommended OC (Hardenburg et al., 1986) without serious loss of quality. However, texture and fibrousness were not measured. The use of CA storage $\left(2.4 \% \mathrm{O}_{2}\right.$ with or without $2.6 \%$ or $4.7 \% \mathrm{CO}_{2}$ ) further extended the shelf life to 21 days at $10 \mathrm{C}$, but the effect of low $\mathrm{O}_{2}$ was greater than that of high $\mathrm{CO}_{2}$. Storage at temperatures near the recommended $0 \mathrm{C}$ maintains the quality of sugar peas for 21 days. Robinson et al. (1975) found that 'Kelvedon Wonder' peas could be stored for 1.5 to 3 weeks at 1 to $2 \mathrm{C}$.

Our results showed that CA treatments of $2.4 \% \mathrm{O}_{2}$ maintained quality of sugar peas for periods of up to 3 weeks at higher than recommended storage temperatures. Increasing the $\mathrm{CO}$, levels to $2.6 \%$ or $4.7 \%$ had no adverse effects on quality. While CA may not currently be economical on a commercial basis, the use of plastic films may be an economically feasible method to produce beneficial modified atmospheres.

\section{Literature Cited}

Arnon, D.I. 1949. Copper enzymes in isolated chloroplasts. Polyphenoloxidase in Beta vulgaris. Plant Physiol. 24:1-15.

Dubois, M., K.A. Gilles, J.K. Hamilton, P.A Rebers, and F. Smith. 1956. Colorimetric method for determination of sugars and related substances. Anal. Chem. 28:350-356

Groeschel. E.C.. A.I. Nelson. and M.P. Steinberg. 1966. Changes in color and other characteristics of green beans stored in controlled refrigerated atmospheres. J. Food Sci. 3:488 496.

Hardenburg, R.E., A.E. Watada, and C.Y. Wang. 1986. The commercial storage of fruits, vegetables, and florist and nursery stocks. U.S. Dept. Agr. Hdbk. 66, Washington, D.C.

Kader, A., W.J. Lipton, and L.L. Morris. 1973. Systems for scoring quality of harvested lettuce. HortScience 8:408-409.

Lowry, O.H., N.J. Rosebrough, A.L. Farr, and R.J. Randall. 1951. Protein measurement with the folin phenol reagent. J. Biol. Chem. 193:265 215.

Miller, E.V. and C. Brooks. 1932. Effect of carbon dioxide content of storage atmosphere on carbohydrate transformation in certain fruits and vegetables. J. Am. Res. 45:449-459.

Miller, E.V. and O.J. Dowd. 1936. Effect of carbon dioxide on the carbohydrates and acidity of fruits and vegetables in storage. J. Agr. Res. $53: 1-17$

Morris, L.L. 1969. A two-stage, flow-through system for vegetables. Proc. Natl. CA Res Conf., Michigan State Univ. (Hort. Rpt. 9):1316.

Paull, R., N.J. Chen, and J. Deputy. 1984. Litchi growth and compositional changes during fruit development. J. Amer. Soc. Hort. Sci. 109:817821.

Robinson, J.E., K.M. Browne, and W.G. Burton. 1975. Storage characteristics of some vegetables and soft fruits. Ann. Applied Biol. 8:399408.

Singh, B., D.J. Wang, and D.K. Salunkhe. 1972 Controlled atmosphere storage of lettuce. 2. Effects on biochemical composition of leaves. J. Food Sci. 37:52-55.

Tewfik, S. and L.E. Scott. 1954. Respiration of vegetables as affected by postharvest treatment. J. Agr. Chem. 2:415-417.

Thimann, K.V. 1980. The senescence of leaves, p. 85-115. In: K.V. Thimann (ed.). Senescence in plants. CRC Press, Boca Raton, Fla.
Tomkins, R.G. 1957. Peas kept for 20 days in gas storage. The Grower 48(5):226-227.

Wang, C.Y. 1983. Postharvest responses of Chinese cabbage to high $\mathrm{CO}_{2}$ treatment or low $\mathrm{O}_{2}$ storage. J. Amer. Soc. Hort. Sci. 108:125-129.

\title{
Catalase Polymorphism and Inheritance in Peach
}

\author{
Dennis J. Werner \\ Department of Horticultural Science, North Carolina State University, \\ Raleigh, NC 27695-7609
}

Additional index words. allozyme, electrophoresis, Prunus persica

Abstract. Catalase isozymes were examined in a wide range of peach [ Prunus persica (L.) Batsch] cultivars representing historical U.S. cultivars, commercial cultivars from numerous North American breeding programs, and the peach plant introduction (PI) collection. All historical peach cultivars from the United States and those released from commercial breeding programs were fixed for the slow ( Cat 1-2) allele, with the exception of 'Belle of Georgia', 'Honeyglo' nectarine, and various cultivars from the Univ. of Florida breeding program, which possessed $a$ fast-migrating ( Cat 1-1) allele in homozygous or heterozygous state. Polymorphism was revealed in the 51 peach PI clones examined, with allelic frequencies of 0.69 and 0.31 for the $\mathrm{Cat} \mathrm{I}-2$ and $\mathrm{Cat} \mathrm{l}-1$ alleles, respectively. Most PIs that originated directly from China were homozygous Cat $1-1 /$ Cat l-1, while most PI clones introduced from Europe were homozygous Cat 1-2 / Cat l2. Examination of the catalase genotype of cultivars previously proposed as the possible male parent of 'Belle of Georgia' ('Champion', 'Early Crawford', 'Late Crawford', 'Oldmixion Free', and 'Stump-the-World') revealed that none of these cultivars could have been the male parent of 'Belle of Georgia'. Segregation data from various peach crosses was consistent with the hypothesis that catalase polymorphism could be explained by the presence of two alleles at a single locus.

Limited isozyme polymorphism has been reported in peach, despite variability for numerous morphological traits. Previous research has identified polymorphism in six enzyme systems (Arulsekar et al., 1986; Durham et al., 1987; Messeguer et al., 1987; Mowrey et al., 1990). Isozymes are useful as molecular markers in genetic linkage studies; however, polymorphism is a prerequisite for their use in such studies. The objective of this study was to examine a comprehensive collection of peach cultivars and the U.S. Dept. of Agriculture's (USDA) peach PI collection for catalase polymorphism. The inheritance of catalase is also reported.

Numerous cultivars (Table 1) and 51 peach PIs (Table 2) were examined in this survey. Cultivars examined were representative of

Received for publication 14 Feb. 1991. I thank Steve Worthington and Dana Moxley for technical assistance, Bruce Mowrey for developing many of the populations used in this study, and Dick Okie, U.S. Dept. of Agriculture, Byron, Ga.. and Wayne Sherman, Fruit Crops Dept., Univ. of Florida, for providing plant samples. Research supported from funds provided by the North Carolina Agricultural Research Service, Raleigh. The cost of publishing this paper was defrayed in part by the payment of page charges. Under postal regulations, this paper therefore must be hereby marked advertisement solely to indicate this fact. commercial germplasm developed in U.S. breeding programs, with special emphasis placed on cultivars released from the Univ. of Florida; USDA, Byron, Ga.; and North Carolina State Univ. breeding programs. Historical cultivars of North American origin distinct from the germplasm base represented by cultivars originating from North American breeding programs were also examined. Eight seedling populations segregating for catalase were examined to determine the inheritance of catalase.

Fully expanded leaves $\approx 6 \mathrm{~cm}$ from the terminal bud were collected from actively growing shoots of field-grown trees in Summer 1990. Catalase was characterized on lithium borate/Tris.citrate starch gels (Stuber et al., 1988) using previously described electrophoretic procedures (Mowrey et al., 1990), except that the modified stone-fruit extraction buffer of Arulsekar and Parfitt (1986) was used. The extraction buffer was modified by deleting polyethylene glycol, L-cysteine, and $\beta-$ mercaptoethanol. Gels were run for $6 \mathrm{~h}$ at $13 \mathrm{~W}$ of constant power. All cultivars and PIs were characterized twice for catalase using two independent electrophoretic runs. Progeny of seedling populations were characterized only once. Goodness-offit of observed segregations to the appropriate genotypic test ratio was conducted using chi-square analysis. Migration distances were 
Table 1. Peach cultivars grouped by catalase genotype.

\begin{tabular}{ll}
\hline $\begin{array}{l}\text { Catalase } \\
\text { genotype }\end{array}$ & \multicolumn{1}{c}{ Cultivars } \\
\hline $1-1 / 1-1$ & Barton, Florida Evergreen, Harrow Blood, Okinawa, Pillar \\
$1-1 / 1-2$ & Belle of Georgia, Flordastar, Honeyglo(n), Oro A, TropicBeauty \\
$1-2 / 1-2$ & Aqua 6-4, Bailey, Bicentennial, Blake, Camden, Candor, Carolina Belle, \\
& Champion, Chinese Cling, Clayton, Contender, Coronet, Cresthaven, Dur- \\
& bin(n), Early Crawford, Elberta, Emery, Encore, Fireprince, Flavortop(n), \\
& Flordadawn, Flordaglo, Flordaglobe, Golden Jubilee, Goldprince, Hamlet, \\
& Hardired(n), Heath Cling, J.H. Hale, June Gold, Juneprince, Late Craw- \\
& ford, Majestic, Mayflower, Maygold, Monroe, Norman, O'Henry, Old- \\
& mixion Free, Parade, Redcap, Redgold(n), Redskin, Reliance, \\
& Roseprincess(n), Salway, Scarletpearl(n), Sentinel, Springbrite, Spring- \\
& crest, Springold, Starlite, St, John, Stump-the-World, Summer Beaut(n), \\
& Summer Pearl, Sunblaze(n), Sundowner(n), Sungem(n), Sunglo(n), Sun- \\
& high, Sunland, Sunprince, Sunred(n), Surecrop, Topaz, TropicSweet, Win- \\
blo & \\
\hline
\end{tabular}

$\mathrm{x}_{\mathrm{n}}=$ nectarine.

Table 2. Peach plant introduction (PI) clones grouped by catalase genotype. See Mowrey et al. (1990) for names and origins of plant introductions.

\begin{tabular}{lc}
\hline $\begin{array}{l}\text { Catalase } \\
\text { genotype }\end{array}$ & \multicolumn{1}{c}{ PI no. } \\
\hline $1-1 / 1-1$ & $55776,62602,65821,95501,101663,101667,101668,101686,102705$, \\
& $112033,113455,134401,151158$ \\
$1-1 / 1-2$ & $36126,106062,119846,125025,129674,146137$ \\
$1-2 / 1-2$ & $34685,43289,55836,63850,65974,65977,77876,78544,82413,93826$, \\
& $101823,101835,104488,105362,112032,119840,119844,125017$, \\
& $129678,130980,131034,131075,131209,132007,133551,133741$, \\
& $133982,133984,133987,134150,134151,442380$ \\
\hline
\end{tabular}

Table 3. Genotypic ratios and goodness-of-fit for the catalase-1 locus in peach crosses.

\begin{tabular}{|c|c|c|c|c|c|c|}
\hline \multirow[b]{2}{*}{ Cross } & \multicolumn{3}{|c|}{$\begin{array}{c}\text { Catalase } \\
\text { segregation classes }\end{array}$} & \multirow{2}{*}{$\begin{array}{l}\text { Test } \\
\text { ratio }\end{array}$} & \multirow[b]{2}{*}{$\chi^{2}$} & \multirow[b]{2}{*}{$P$} \\
\hline & $1-1 / 1-1$ & $1-1 / 1-2$ & $1-2 / 1-2$ & & & \\
\hline Redhaven $(1-2 / 1-2) \times$ PI $101668(1-1 / 1-1)$ & 0 & 39 & $1^{z}$ & $\ldots$ & $\ldots$ & $\ldots$ \\
\hline PI $146137(1-1 / 1-2) \times$ PI $101668(1-1 / 1-1)$ & 17 & 17 & 0 & $1: 1$ & 0 & 0.99 \\
\hline PI $119840(1-2 / 1-2)$ x PI $101668(1-1 / 1-1)$ & 0 & 20 & 0 & $\ldots$ & $\ldots$ & $\ldots$ \\
\hline PI $104488(1-2 / 1-2)$ x PI $129674(1-1 / 1-2)$ & 0 & 15 & 24 & $1: 1$ & 2.08 & 0.15 \\
\hline PI $146137(1-1 / 1-2) \times$ Redhaven $(1-2 / 1-2)$ & 0 & 37 & 37 & $1: 1$ & 0 & 0.99 \\
\hline PI 129674 (1-1/1-2) self-pollinated & 11 & 16 & 7 & $1: 2: 1$ & 1.06 & 0.59 \\
\hline Belle of Georgia $(1-1 / 1-2)$ self-pollinated & 6 & 29 & 15 & $1: 2: 1$ & 4.54 & 0.1 \\
\hline PI $55776(1-1 / 1-1)$ self-pollinated & 30 & $m$ & $\ldots$ & $\ldots$ & $\ldots$ & $\ldots$ \\
\hline
\end{tabular}

2This individual probably represents an accidental self-pollination.

recorded to the nearest millimeter. Relative migration ( $\mathrm{Rm}$ ) for each band and allelic designations were assigned as described by Mowrey et al. (1990).

Catalase is a tetrameric enzyme in plants (Stuber et al., 1988). Three catalase banding

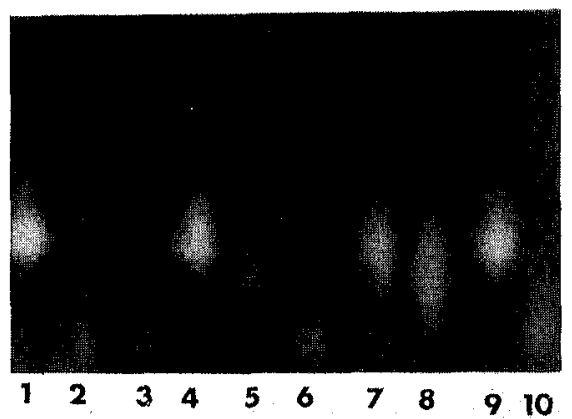

Fig. 1. Isozyme banding patterns observed in peach. Lanes $1,4,7$, and $9=$ homozygous Cat $1-1 /$ Cat $1-1$; lanes $2,3,6$, and $10=$ homozygous Cat $1-2 / C a t 1-2$; lanes 5 and $8=$ heterozygous Cat $1-1 /$ Cat $1-2$. Origin at bottom of photograph. patterns were detected in this study (Fig. 1). Observed segregation in peach (Table 3 ) is consistent with the hypothesis that the variation is controlled by two alleles at one locus. Homozygous individuals were characterized by a fast $(\mathrm{Rm}=1.00)$ or a slow $(\mathrm{Rm}$ $=0.22$ ) homotetrameric band. The fast band generally showed better resolution and stained more intensely than the slow band (Fig. 1), with the slow band often showing a streaked phenotype similar to the Cat 3-7 allele in corn (Goodman and Stuber, 1983). Allelic designations of Cat 1-1 and Cat 1-2 are proposed for the catalase alleles producing the fast and slow bands, respectively, in peach. Because of the tetrameric structure of catalase, heterozygous individuals should have five bands. In our study, heterozygous individuals usually showed a streaked band intermediate between the fast and slow bands, rather than five discrete bands on the gel (Fig. 1). Occasionally, five discrete bands could be discerned on gels showing good resolution.

Most commercial cultivars surveyed in this study that were released from North Amer- ican breeding programs were fixed for the slow (Cat 1-2) allele (Table 1). This result is not surprising, because most commercial peach cultivars in the United States have been developed from a germplasm base that traces back to the single cultivar Chinese Cling that was homozygous for the Cat 1-2 allele (Scorza et al., 1985). Interestingly, 'Belle of Georgia' (a seedling from a 'Chinese Cling' outcross) was heterozygous, indicating that its male parent must have contributed the Cat $1-$ 1 allele. 'Belle of Georgia', a clone of historical importance in the United States, was discovered and named by Samuel Rumph of Marshallville, Ga., in the 1870s (Hedrick, 1917). Although the male parent of 'Belle of Georgia' is not known, Rumph and others have proposed that 'Oldmixion Free' is the likely male parent (Hedrick, 1917; Myers et al., 1989). 'Early Crawford', 'Late Crawford', 'Stump-the-World', and 'Champion' were also proposed as the possible male parent of 'Belle of Georgia' (Myers et al., 1989). Fortunately, all these cultivars still exist, and electrophoretic analysis of leaf samples obtained from each cultivar from the USDA germplasm collection at Byron revealed that all five of these cultivars are homozygous Cat 1-2 / Cat 1-2. Thus, based on catalase, none of these cultivars could have been the male parent of 'Belle of Georgia'.

Examination of the 14 cultivars surveyed from the Univ. of Florida breeding program revealed that three clones were homozygous Cat 1-1 / Cat 1-1, three were heterozygous Cat 1-1 / Cat 1-2, and eight were homozygous Cat 1-2 / Cat 1-2. The existence of catalase polymorphism in the Florida germplasm can be explained by the wide genetic base of the breeding material. Unique germplasm was introduced early into this program to provide a source of genes for low chilling requirement. Interestingly, the three clones from this program that were homozygous Cat 1-1/ Cat 11, ('Okinawa', 'Florida Evergreen', and 'Barton') all originated from southern China and have a very low chilling requirement. 'Okinawa' was one of the primary cultivars used in the Florida program as an initial source of genes for low chilling requirement. 'Barton' is a rootstock cultivar used in Australia.

Catalase polymorphism was also present in the peach PI collection (Table 2). The existence of polymorphism in this collection is not surprising because these clones are highly variable for bloom date, fruit size and quality, and other traits (Ackerman, 1957). Frequencies of the Cat 1-1 and Cat 1-2 alleles in the PI collection were 0.31 and 0.69 , respectively. Of the 51 PIs examined, 13 were homozygous Cat 1-1/Cat 1-1, and 32 were homozygous Cat 1-2 / Cat 1-2. A low frequency of heterozygous individuals in the PIs is probably due to the high rates of selfpollination that occur in peach. A low frequency of heterozygous individuals was also observed for isocitrate dehydrogenase in the peach PIs (Mowrey et al., 1990). Cat 1-1 was the most common allele in clones originating directly from China, occurring in nine out of 10 clones, while 13 clones of European origin were all monomorphic for Cat 1 - 
2 (see Mowrey et al., 1990, for origin of peach plant introductions). A similar trend was found for the Mdh 1-3 and Mdh 1-2 alleles in peach (Mowrey et al., 1990).

This study identified a new genetic marker in peach and further substantiates that the North American germplasm base of peach is very narrow. Further, allozyme variation revealed in this and a previous study (Mowrey et al., 1990) of the PI collection suggests that this collection should be examined for other valuable qualitative and quantitative traits.

\section{Literature Cited}

Ackerman, W.L. 1957. Evaluation of foreign fruits and nuts. No. 8. Late blossoming peach and nectarine varieties tested at Chico, California. U.S. Plant Intro Garden, California Crops Res.
Div., Agr. Res. Serv./U.S. Dept. Agr.

Arulsekar, S. and D.E. Parfitt. 1986. Isozyme analysis procedures for stone fruits, almond, grape, walnut, pistachio, and fig. HortScience 21:928-933.

Arulsekar, S., D.E. Parfitt, W. Beres, and P.E. Hansche. 1986. Genetics of malate dehydrogenase isozymes in peach. J. Hered. 77:49-51.

Durham, R.E., G.A. Moore, and W.B. Sherman. 1987. Isozyme banding patterns and their usefulness as genetic markers in peach. J. Amer. Soc. Hort. Sci. 112:1013-1018.

Goodman, M.M. and C.W. Stuber. 1983. Maize, p. 1-33. In: S.D. Tanksley and T.J. Orton (eds.). Isozymes in plant genetics and breeding. Part B. Elsevier, Amsterdam, Netherlands.

Hedrick, U.P. 1917. The peaches of New York. Rpt. New York Agr. Expt. Sta. 1916.

Messeguer, R., P. Arus, and M. Carrera. 1987.
Identification of peach cultivars with pollen isozymes. Scientia Hort. 31:107-117.

Mowrey, B.D., D.J. Werner, and D.F. Byrne. 1990. Inheritance of isocitrate dehydrogenase, malate dehydrogenase, and shikimate dehydrogenase in peach and peach $\mathrm{x}$ almond hybrids. J. Amer. Soc. Hort. Sci. 115:312-319.

Myers, S.C., W.R. Okie, and G. Lightner. 1989. The 'Elberta' peach. Fruit Var. J. 43:138-13X.

Scorza, R., S.A. Mehlenbacher, and G.W. Lightner. 1985. Inbreeding and coancestry of freestone peach cultivars of the eastern United States and implications for peach germplasm improvement. J. Amer. Soc. Hort. Sci. 110:547-552.

Stuber, C.W., J.F. Wendel, M.M. Goodman, and J.S.C. Smith. 1988. Techniques and scoring procedures for starch gel electrophoresis of enzymes from maize (Zea mays L.). North Carolina Agr. Res. Serv. Tech. Bul. 286.

HORTSCIENCE 27(1):43-44. 1992.

\section{Use of Stored Pollen to Hybridize a Mandarin Hybrid and Citrus tachibana}

\section{Randall P. Niedz ${ }^{1}$, Michael G. Bausher ${ }^{2}$, and C. Jack Hearn ${ }^{3}$ Horticultural Research Laboratory, U.S. Department of Agriculture- Agricultural Research Service, 2120 Camden Road, Orlando, FL 32803}

Additional index words. fruit breeding, isozymes, tachibana orange, glutamateoxaloacetate transaminase

\begin{abstract}
Fresh pollen from Citrus tachibana Macf. was oven-dried (37C), freezedried, or placed into anhydrous acetone, and stored at $-20 \mathrm{C}$ over silica gel. Pollen freeze-dried or stored in anhydrous acetone did not germinate 24 hours after treatment; oven-dried pollen germinated in 1 hour and was comparable to fresh pollen. Pollen that was oven-dried for 12 hours and stored for 1 year was used to pollinate a monoembryonic hybrid of 'Temple' (origin unknown) $\mathrm{x}$ 'Orlando' (C. paradisi Macf. 'Duncan'xC. reticulata Blanco 'Dancy'). Glutamate-oxaloacetate transaminase (GOT) isozyme profiles verified progeny hybridity.
\end{abstract}

Citrus species are all sexually compatible, although some inter- or intraspecific hybrids are difficult to create because of varying degrees of facultative apomixis (Barrett and Rhodes, 1976). Use of C. tachibana (tachibana orange) germplasm in the U.S. Dept. of Agriculture-Agricultural Research Service (USDA-ARS) breeding program has not been possible for two reasons. First, C. tachibana is highly apomictic (C.J.H. and D.J.

Received for publication 5 Mar. 1991. Mention of a trademark, warranty, proprietary product, or vendor does not constitute a guarantee by the U.S Dent. of Agriculture and does not imply its approval to the exclusion of other products or vendors that may also be suitable. We thank Delores F. Lomberk for her competent assistance and Randall C. Smith for preparing the figure. The cost of publishing this paper was defrayed in part by the payment of page charges. Under postal regulations, this paper therefore must be hereby marked advertisement solely to indicate this fact:

${ }^{1}$ Research Geneticist.

${ }^{2}$ Research Plant Physiologist.

${ }^{3}$ Research Geneticist.
Hutchison, unpublished); most seedlings are nucellar in origin, thus precluding its use as a seed parent. Second, it flowers in the Orlando area 4 to 6 weeks later than most other Citrus spp. and hybrids, thus preventing its use as a pollen parent. The purpose of this work was to determine if tachibana orange pollen could be stored for 1 year with sufficient viability to be used in controlled hybridizations.

Unopened flowers approaching anthesis were collected in Apr. 1988 from a mature C. tachibana tree growing in the germplasm collection at the USDA-ARS, A.H. Whitmore Research Farm near Leesburg, Fla. Flowers were stored in covered polystyrene dishes at $25 \mathrm{C}$ until anthesis and pollen dehiscence, and anthers were cut from the filaments with a scalpel. Fresh anthers were oven-dried at $37 \mathrm{C}$ for $3,6,12$, or $24 \mathrm{~h}$; or 4 , or $8 \mathrm{~h}$. Dried anthers were stored in 1.5 $\mathrm{ml}$ microcentrifuge tubes over silica gel at -20C. Pollen and anthers were also stored at $-20 \mathrm{C}$ in anhydrous acetone prepared by freeze-dried (-40C, 10 millitorr) for 1,2 , mixing S-mesh Drierite (W.A. Hammond Drierite, Xenia, Ohio) with acetone for $1 \mathrm{~h}$, and then filtering through Whatman no. 1 filter paper (Thomas Scientific, Swedesboro, N.J.) to remove the hydrate. The entire process was repeated two more times. This pollen was also removed $24 \mathrm{~h}$ later, washed three times in distilled water $\left(\mathrm{dH}_{2} \mathrm{O}\right)$, rehydrated, germinated, and stained.

Anthers were removed from cold storage and tested for pollen viability $24 \mathrm{~h}$ later. They were poured onto a glass slide and placed into a polystyrene dish over wet filter paper for $1 \mathrm{~h}$ to rehydrate the pollen. Pollen was germinated in Brewbaker's medium (Sahar and Spiegel-Roy, 1980) for $4 \mathrm{~h}$ at 27C, stained with Alexander's stain (Alexander, 1980), and counted to determine viability. At least 1000 pollen grains were counted per treatment. A pollen grain was considered viable if tube length exceeded grain diameter. Stored pollen was used the next season to pollinate emasculated flowers of a seedy, monoembryonic 'Temple' x 'Orlando' hybrid. Flowers were bagged after pollination, although this is generally unnecessary in Citrus breeding as honeybees, the primary Citrus pollen vectors, do not visit flowers after the petals have been removed (C.J.H. and D.J. Hutchison, unpublished), and wind is not a sig-

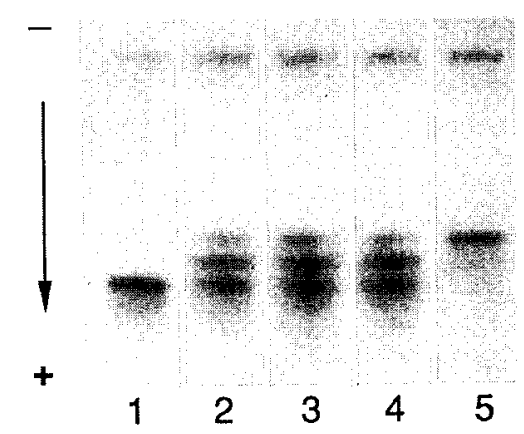

Fig. 1. GOT isozyme profiles of $C$. tachibana, 'Temple' $x$ 'Orlando' hybrids, and three hybrid seedlings. Lane $1, C$. tachibana; lanes $2-4$ hybrids of ('Temple' $x$ 'Orlando') $\times C$. tachibana; lane 5, 'Temple' $x$ 'Orlando' seed parent. 